\title{
IAMJ
}

INTERNATIONAL

AYURVEDIC

MEDICAL JOURNAL

ISSN: $2320-5091$

Impact Factor: 6.719

\section{VARIOUS DIMENSIONS OF DAIVAVYAPASHRAYA WITH ITS POSSIBLE RATIONALITY - A JIGNASA}

\section{Sowjanya. J}

Assistant Professor, Department of Kayachikitsa, S D M Institute of Ayurveda and Hospital, Bengaluru, Karnataka, India

Corresponding Author: sowjukool93@gmail.com

\section{https://doi.org/10.46607/iamj10p5052021}

(Published online: July 2021)

Open Access

(C) International Ayurvedic Medical Journal, India 2021

Article Received: 05/07/2021 - Peer Reviewed: 21/07/2021 - Accepted for Publication: 22/07/2021

Check for updates

\section{ABSTRACT}

"Shubham Karoti Kalyanam Arogyam Dhanasampadaha Shatrubuddhi Vinashaya Deepajyoti Namostute".

The concept of Daivavyapashraya chikitsa has been misunderstood as magical therapy which is wrong, as Acharya Charaka has emphasized it as the prime most among Trividhaushadhi's in Trisreshaneeyaadhyaya due to its Aashu vyadhiharatwatana, which highlights its importance among all three treatment modalities. Daiva refers to Adrushta and Vyapashraya to Visheshena ashrayam. Hence a review on the art of invocation and implanting it by preventing and curing Physical and Psychosocial diseases with a proper scientific approach is very much essential. Daivavyapashrayachikitsa comprises MantrAoushadhaManiMangalaBaliaadi. Many instances are available in the Samhitha's such as, 'Siddhamantrapatana' in the treatment of AagantujaUnmada, 'Sahadeevimooladharana' in the case of Vishamajwara, which is purely scientific. Acharya Sushrutha in Uttaratantra quotes the concept of Bali and Rakshavidhanam as a treatment in the case of each Grahabhada in children. For example: In case of Skandhagraha Raktamaala, Pataka, Raktagandhadravyas, Raktabhakshya, KukkutaBali along with Ghantanaada and ShivaParvati Mantrapatana. The rationality behind it can be interpreted as, it acts on microbial activity, negative energy and child's psychology, as well as the Mantra's, which are energy-based sounds that act on a particular system of the body and mind. Since the word Daiva is quoted in different contexts with different meanings as Adrushta, Poorvadaihikakarma and based on the aspects explained under Daivavyapashrayachikitsa, rationality 
can be interpreted as Microbiology, Psychology, Spiritualism, Philosophy, Astrology and Paranormal sciences are included in it. Thus, an attempt is made in understanding and practicing Daivavyapashrayachikitsa along with the scientific approach.

Keywords: Daivavyapashrayachikitsa, Psychology, Sushrutha

\section{INTRODUCTION}

Daivavyapashrayachikitsa- a boon to the Ayurvedic physicians, which prevents and cures many diseases, has been under the heap of ash at the present scenario. Understanding and practising it with a rational approach must be inculcated. A part of science that is unique, forgotten and becoming extinct should be reviewed and practised. Thus, a thought process has been incorporated on various dimensions and rationality of Daivavyapashrayachikitsa mentioned in the Samhitha's.

DAIVAVYAPASHRAYA CHIKITSA: In our science, each and everything is concealed within Kaarya Karana Siddhanta and thus Daivavyapashraya Chikitsa too. It is explained for specific diseases with specific pathogenesis and not for all diseases. An approach towards its rationality has been made as follows:

1. Mantra Chikitsa: Mantras are the energy-based vibrations that act on each cell in our body based on the composition. For ample of diseased conditions and preventive aspect, Mantra chikitsa has been quoted in our Samhitha's as

Vishnusahasranama for Vishamajwara ${ }^{1}$, Gayatrimantra pathana for Rasayana and Vasheekarana ${ }^{2}$, Shreesookta, Mahendra, Rama, Krishna, Shiva mantras for Rasayana aushadha sevana ${ }^{3}$, Rudrastuti for Shoosha ${ }^{4}$, Vedadhyayana for Prameha ${ }^{5}$ and so on.

2. Aushadha Chikitsa: These are the medicinal plants with special properties mentioned specially for those diseases which are caused due to Poorvajanmakarmaphala and should be consumed with proper rituals. Such references are available as Dhanwana Shalmalyadi aushadhisevana along with Mantra patana for Moodhagarbha nirharanartha ${ }^{7}$, in children to prevent Grahabhada
Brahmi, Aindri, Jeevaka, vacha aushadhis to be made worn in hands, neck, and head respectively ${ }^{8}$.

3. Mani Dharana: Wearing a particular Mani for a particular Graha has been mentioned which emphasizes Mani Dharana is related to both astrology and medical science. Maanikya (Ruby) has been mentioned for Soorya Graha badha, as it is sheeta, snigdha it acts tremendously against Soorya graha which is ushna, Teekshna. In medical science, it has been mentioned as, Mukta Sphatika Mani Dharana for Moorcha chikitsa ${ }^{9}$, Manidharana as one of the treatment modalities for all Pittaja vikaras ${ }^{10}$.

4. Mangala Karma: Performing pleasing rituals such as offering Pooja for Brahma, Ashwinau, Indra, Ishwaradi devatas in case of Vishamajwara ${ }^{1}$, Ishwara pooja in Case of Unmada and Apasmara $^{11}$, this calms the mind and reduces the symptoms by acting on CNS of the diseased person.

5. BaliUpahara Karma: Many instances are available such as, in the case of each Grahabhada in children's different kinds of offerings has been quoted. For Skandhagraha Raktamaala, Pataka, Raktagandhadravyas, Raktabhakshya, KukkutaBali along with Ghantanaada and ShivaParvati Mantrapatana $^{12}$, For Rutuvyapad chikitsa, Deevatanam pashubali ${ }^{06}$ has been mentioned. The rationality behind it can be interpreted as; it acts on microbial activity, negative energy and a child's psychology.

6. Homa-Havana-Dhoopana Karma and Rakshavidhana: Fumigation therapy not only destroys microbial activity but also reduces negativity and uplifts spiritualism in and around the surroundings. For example, Ishta Homa to cure Unmada and Apasmara ${ }^{11}$, Nitya kshatatura 
rakshanartha Guggulwadi Dhoopana ${ }^{13}$ and for all kinds of Grahabhada, Raksha karma, Dhoopana has been mentioned.

7. Niyama: These are the set of rules and regulations one has to follow to prevent and get rid of the diseases which act on behaviour patterns and specific systems of the person. It includes Akrodha, Gurusushrusha, Shoucha, Aharalaghava and Apramada. For instance: In the case of Kushta Vratadi Niyama seeva has been quoted ${ }^{14}$.

8. Prayashittha: Accepting one's own mistakes, repenting and surrendering even though looks like a philosophy, will help in resolving many incurable conditions. It has been mentioned as a treatment for AbhishapaAbhicharaja jwara ${ }^{15}$ and also for many such conditions.

9. Upavasa: Emphasizes many contextual meanings such as 'being nearer to good or god', 'fasting' etc. While stating Rutuvyapad chikitsa, Upavasa has been mentioned as a treatment modality ${ }^{06}$, which controls physical and psychological aspects in diseased and also acts as a preventive aspect.

10. Swastyayana: Refers to chanting or saying good aspects such as Shanti mantras. In Unmada and Apasmara Shanti mantras $^{11}$, in Rutuvyapad Chikitsa vedokta mantras for swastyayanartha ${ }^{06}$ have been mentioned.

11. Pranipatagamana: Performing Namaskara to Deevaadi along with Teerthaksheetra darshana focuses oneself and helps in preventing and curing many challenging diseases. While explaining Klaibya chikitsa prime most importance has been given to $\mathrm{it}^{16}$.

12. Aadi: Refers to many other concepts such as Japa, Tapa, Sadhudarshana, Agadadharana, Mrutasanjeeveni, Daana, Sthanaparityaga, and Ashwasana which all interprets Daivavyapashraya Chikitsa itself. Along with it many concepts directly emphasize Daivavyapashrayachikitsa such as Achara Rasayana, Aushadha mantra quoted in Vamana vidhi, Sadvrutta paripalana, Rutucharya, Punsavanavidhi, Tarpanavidhi, Mantra patana before Shastrakarma.

\section{DISCUSSION}

Daivavyapashrayachikitsa is indicated in both Shaareerika and Manasika vyadhi's as well as for all karmaja Vyadhi's.

Along with a literary review on Daivavyapashraya Chikitsa, a clinical approach has been adopted while treating subjects of Vishamajwara by incorporating chanting of Vishnusahasranama, which had yielded better results.

While explaining Ashtanga's of Ayurveda Bhootavidya/Grahavidya has been quoted and it denotes its prime importance in Ayurveda, which is getting vanished and extinct nowadays.

Based on its importance, the present study is established on Daivavyapashrayachikitsa as a sparkle of light, highlighting the possible rationality by taking into consideration all sciences such as Microbiology, Psychology, Spiritualism, Philosophy, Astrology and Paranormal sciences.

\section{CONCLUSION}

Daivavyapashraya Chikitsa as indicated in all kinds of Psycho-somatic disorders can be incorporated as a special entity to treat all such diseases which requires multi-dimensional clinical studies.

Rather than only limiting a special and unique treatment modality, its rationality to be understood and it should be brought into practice by various clinical studies which is very much essential in the present era.

\section{REFERENCES}

1. Vaidya Jadavji Trikamji Acharya Maharshina Charakena Virachita Charaka Samhitha, Sri Chakrapanidattavirachitaya Ayurvedadeepika vyakhyaya, Varanasi, Chaukambha Prakashana, \#Reprint:2019, Chikitsa Sthana 03/309-314, pp.426

2. Maharshina Sushrutena Virachita Sushrutha Samhitha, Ayurvedatatwasandeepika-Hindi vyakhyaya, Vaignyanika Vimarsha, Tippanisahita, PrathamaBhaga (Poorvardha), Kaviraja Ambikadattashastry, Varanasi, Chaukambha Prakashana, \#Reprint:2005, Chikitsa Sthana 30/05,26-28 pp.411-412

3. Maharshina Sushrutena Virachita Sushrutha Samhitha, Ayurvedatatwasandeepika-Hindi vyakhyaya, Vaignyanika Vimarsha, Tippanisahita, PrathamaBhaga 
(Poorvardha), Kaviraja Ambikadattashastry, Varanasi, Chaukambha Prakashana, \#Reprint:2005, Chikitsa Sthana 28/09-12,19-27, pp.407-408

4. Vaidya Jadavji Trikamji Acharya Maharshina Sushrutena Virachita Sushrutha Samhitha, Sri Dalhanacharyavirachitaya Nibanda sangraha vyakhyaya, Sri Gayadasa virachitaya Nyayachandrika vyakhyaya, Narayana Ram Acharya's "Kavyateertha", Varanasi, Chaukambha Prakashana, \#Reprint:2014, Uttaratantra 41/57-58, pp.610

5. Maharshina Sushrutena Virachita Sushrutha Samhitha, Ayurvedatatwasandeepika-Hindi vyakhyaya, Vaignyanika Vimarsha, Tippanisahita, PrathamaBhaga (Poorvardha), Kaviraja Ambikadattashastry, Varanasi, Chaukambha Prakashana, \#Reprint:2005, Chikitsa Sthana 11/11-12, pp.365

6. Maharshina Sushrutena Virachita Sushrutha Samhitha, Ayurvedatatwasandeepika-Hindi vyakhyaya, Vaignyanika Vimarsha, Tippanisahita, PrathamaBhaga (Poorvardha), Kaviraja Ambikadattashastry, Varanasi, Chaukambha Prakashana, \#Reprint:2005, Sutra Sthana 06/21, pp.26

7. Vaidya Jadavji Trikamji Acharya Maharshina Sushrutena Virachita Sushrutha Samhitha, Sri Dalhanacharyavirachitaya Nibanda sangraha vyakhyaya, Sri Gayadasa virachitaya Nyayachandrika vyakhyaya, Narayana Ram Acharya's "Kavyateertha”, Varanasi, Chaukambha Prakashana, \#Reprint:2014, Chikitsa Sthana 14/05-09, pp.372

8. Vaidya Anna Moreshwara Kunte Maharshina VagbhatenaVirachita Ashtanga Hrudaya, Sri Arunadatta Virachitaya Sarvangasundari vyakhyaya, Sri Hemadripranitaya Ayurveda rasayana vyakhyaya, Bombay, Panduranga Jawali, Chikitsa Sthana 14/0509, pp.372

9. Maharshina Sushrutena Virachita Sushrutha Samhitha, Ayurvedatatwasandeepika-Hindi vyakhyaya, Vaignyanika Vimarsha, Tippanisahita, PrathamaBhaga (Poorvardha), Kaviraja Ambikadattashastry, Varanasi, Chaukambha Prakashana, \#Reprint:2005, Uttaratantra /46,14 pp.634

10. Vaidya Anna Moreshwara Kunte Maharshina VagbhatenaVirachita Ashtanga Hrudaya, Sri Arunadatta Virachitaya Sarvangasundari vyakhyaya, Sri Hemadripranitaya Ayurveda rasayana vyakhyaya, Bombay, Panduranga Jawali, Sutra Sthana 13/04-09, pp. 212
11. Vaidya Jadavji Trikamji Acharya Maharshina Charakena Virachita Charaka Samhitha, Sri Chakrapanidattavirachitaya Ayurvedadeepika vyakhyaya, Varanasi, Chaukambha Prakashana, \#Reprint:2019, Chikitsa Sthana 09/33,87-95, pp.470,474

12. Maharshina Sushrutena Virachita Sushrutha Samhitha, Ayurvedatatwasandeepika-Hindi vyakhyaya, Vaignyanika Vimarsha, Tippanisahita, PrathamaBhaga (Poorvardha), Kaviraja Ambikadattashastry, Varanasi, Chaukambha Prakashana, \#Reprint:2005, Uttaratantra /28,7-8,10-14 pp.557

13. Maharshina Sushrutena Virachita Sushrutha Samhitha, Ayurvedatatwasandeepika-Hindi vyakhyaya, Vaignyanika Vimarsha, Tippanisahita, PrathamaBhaga (Poorvardha), Kaviraja Ambikadattashastry, Varanasi, Chaukambha Prakashana, \#Reprint:2005, Chikitsa Sthana /01,132 pp.321

14. Vaidya Anna Moreshwara Kunte Maharshina VagbhatenaVirachita Ashtanga Hrudaya, Sri Arunadatta Virachitaya Sarvangasundari vyakhyaya, Sri Hemadripranitaya Ayurveda rasayana vyakhyaya, Bombay, Panduranga Jawali, Chikitsa Sthana 19/98, pp.718

15. Maharshina Sushrutena Virachita Sushrutha Samhitha, Ayurvedatatwasandeepika-Hindi vyakhyaya, Vaignyanika Vimarsha, Tippanisahita, PrathamaBhaga (Poorvardha), Kaviraja Ambikadattashastry, Varanasi, Chaukambha Prakashana, \#Reprint:2005, Uttaratantra/39,261-262 pp.585-586

16. Vaidya Jadavji Trikamji Acharya Maharshina Charakena Virachita Charaka Samhitha, Sri Chakrapanidattavirachitaya Ayurvedadeepika vyakhyaya, Varanasi, Chaukambha Prakashana, \#Reprint:2019, Chikitsa Sthana 30/191-195, pp.64

\section{Source of Support: Nil Conflict of Interest: None Declared}

How to cite this URL: Sowjanya. J et al: Various Dimensions Of Daivavyapashraya With Its Possible Rationality - A Jignasa. International Ayurvedic Medical Journal \{online\} 2021 \{cited July, 2021\} Available from: http://www.iamj.in/posts/images/upload/3022_3025.pdf 